European Head Office, London

The Macmillan Building

4 Crinan Street

London N1 9XW, UK

Tel +44 (0) 2078434961

Fax +44 (0) 2078434996

e-mail: naturejobs@nature.com

\section{Group European Manager}

Leonie Welss (4954)

European Manager:

Nevin Bayoumi (4978)

UK/ RoW/ Ireland:

Matt Powell (4953), Ben Corp (4974) Andy Douglas (4975)

Holland/ Italy: Nevin Bayoumi (4978)

Scandinavia: Sille Opstrup (4994)

Spain/ Portugal: Leonie Welss

(4954)

Production Manager: Billie Franklin

To send materials use London

address above.

Tel +44 (0) 2078434814

Fax +44 (0) 2078434996

e-mail: naturejobs@nature.com

\section{International}

Advertising Coordinato

Laura Pearson (4977)

Naturejobs web development:

Tom Hancock

Naturejobs online production:

Benlund

European Satellite Offices

France/ Belgium:

Christine Niox-Chateau

$\mathrm{Tel}+33(0) 143201651$

$\mathrm{Fax}+33(0) 143205152$

e-mail: c.nioxchateau@nature.com

Germany/ Austria/ Switzerland:

Patrick Phelan/Kate Tumer

$\mathrm{Tel}+498954905711 /-2$

$\mathrm{Fax}+498954905720$

e-mails: p.phelan@nature.com

ktumer@naturecom

US Head Office, New York

345 Park Avenue South,

10th Floor, New York, NY 10010-1707

$\mathrm{Tel}+18009897718$

Fax +18009897103

e-mail: naturejobs@natureny.com

US Sales Director: Ben Crowe

US Sales Manager: Peyton Mason

US Advertising Coordinator

Ashly de Leon

Japan Head Office, Tokyo

MG Ichigaya Building (5F)

19-1 Haraikatamachi,

Shinjuku-ku,

Tokyo 162-084

Tel +81 332678751

Fax +81332678746

e-mail:k.cowan@naturejp.con

Japan Manager: Kate Cowan

\title{
naturejobs
}

\section{Chemists buck the trend}

A

lthough the US economy weakened last year, job prospects for newly graduated chemists did not, according to a recent report by the American Chemica Society (ACS). The society's recent salary survey shows that for 2001 master's and $\mathrm{PhD}$ graduates, salaries rose by $6-8 \%$ compared with the previous year. The median master's recipient salary last year was $\$ 48,000$, a $\$ 3,000$ increase over the previous year. New $\mathrm{PhDs}$ fared even better, earning on average $\$ 70,000$, up $\$ 5,000$ from the class of 2000 . And unemployment remained unchanged from 2000 , at $3 \%$ for new $\mathrm{PhD}$ chemists and $5 \%$ for freshly minted master's.

The big question remains whether or not these numbers provide a true picture of the present, as they were collected up to October 2001. The economy continued to weaken after that point and, the survey notes, more chemists are going into pharmaceuticals - an area that is showing signs of caution in terms of recruitment this year.

Weak economy or not, chemists have something working in their favour: fewer are being produced in the United States. So unless demand dips sharply, work should be reasonably easy to find - although not necessarily in their sector of choice.

Academia seems a relatively stagnant market for chemists, as it features significantly lower pay than the private sector. Also, traditional industrial chemical manufacturing is fading, but pharmaceuticals and analytical research firms have seen a steady growth in their need for chemists.

A good bet would be that demand will increase again in the second half of the year, but salaries will not go up quite as much. The question of whether or not pharmaceuticals will consolidate further remains one of the biggest unknown factors.

\section{Paul Smaglik}

Naturejobs editor
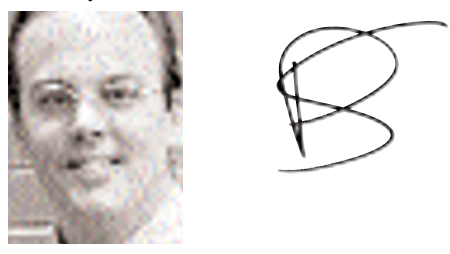

\section{Contents}

\section{POSTDOCS \& STUDENTS}

Bringing the brains back home

\section{MOVERS}

Canberra gets new vicechancellor; one of Dolly's creators heads for Singapore; high-energy physicist takes up the SLAC; and more Back page

\section{WWW.NATUREJOBS.COM}

Career centre

Information on the scientific job market

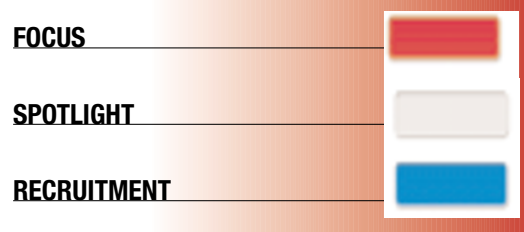

SCIENTIFIC ANNOUNCEMENTS

SCIENTIFIC EVENTS 